\title{
Molecular Investigation of Fibronectin-Binding Protein Genes and Capacity of Biofilm Production in Staphylococcus Aureus Isolated From Clinical Samples
}

Hossein Jafari Soghondicolaei

Mazandaran University of Medical Sciences Faculty of Medicine

Mohammad Ahanjan

Mazandaran University of Medical Sciences Faculty of Medicine

Mehrdad Gholami

Mazandaran University of Medical Sciences Faculty of Medicine

Bahman Mirzaei

Zanjan University of Medical Sciences

Hamid Reza Goli ( $\sim$ h.goli@mazums.ac.ir)

Mazandaran University of Medical Sciences Faculty of Medicine

\section{Research Article}

Keywords: Staphylococcus aureus, Biofilm, MDR, fnbA, fnbB

Posted Date: June 24th, 2021

DOI: https://doi.org/10.21203/rs.3.rs-640880/v1

License: (c) (1) This work is licensed under a Creative Commons Attribution 4.0 International License.

Read Full License 


\section{Abstract}

Biofilm production increases Staphylococcus aureus resistance to antibiotics and also host defense mechanisms. The current study aims to evaluate the biofilm formation by $S$. aureus and to determine the prevalence of fibronectin-binding protein genes, also its correlation with drug resistance. In this study, 100 clinical isolates of $S$. aureus were collected. The antibiotic susceptibility pattern of the isolates was evaluated by the disk agar diffusion method. The ability of biofilm formation in the studied isolates was also determined by microplate colorimetric assay. Then, all isolates were screened by polymerase chain reaction for the $f n b A$ and $f n b B$ genes. Out of 100 clinical isolates of $S$. aureus, the highest and lowest antibiotic resistance rates were against penicillin (94\%) and vancomycin $(6 \%)$. Thirty-two cases were found to be multi-drug resistant (MDR) among the all strains. The ability of biofilm production was observed in $89 \%$ of the isolates. The PCR results showed that the prevalence of $f n b A$ and $f n b B$ genes were $91 \%$ and $17 \%$, respectively. Moreover, $100 \%$ and $21.8 \%$ of the MDR strains harbored the $f n b A$ and $f n b B$ genes respectively. The ability to form biofilm in MDR isolates of $S$. aureus is more than non-MDR isolates, especially $f n b A$ positive ones. As the bacteria in the biofilm are difficult to kill by antibiotics, attention to the removal or control of the biofilm production seems to be necessary.

\section{Introduction}

Staphylococcus aureus is one of the most important bacterial infectious agents in hospitals and also the most common cause of food poisoning(1). It causes a wide range of infections ranging from simple skin infections such as boils, furuncle, carbuncle, sty, and abscesses to life-threatening diseases such as pneumonia, meningitis, osteomyelitis, endocarditis, toxic shock syndrome, and septicemia(2).Moreover, this organism is capable to produce many toxins including enterotoxins, Panton-valentine toxin, and exfoliative toxin(3). Also, this Gram-positive coccuscan produce polysaccharides and adherent protein factors, which are involved in biofilm production and adherence of $S$. aureus to the surfaces(4). Therefore, the presence of biofilm genes in these bacteria is considered as one of their important pathogenic factors and their investigation is very important(5). Biofilm is a structure composed of a bacterial population that is enclosed by an exopolymeric matrix produced by the bacterium(6). This property gives the bacterium the ability to bind to different levels as well as increase the intrinsic resistance to different antibiotics(6). Biofilms comprise a group of microorganisms that interact with a network of internal channels in the extracellular glycoprotein and polysaccharide matrix called extracellular polymeric material(2). The extracellular polymeric material is composed of polysaccharides, proteins, phospholipids, teichoic acid and other hydrated polymeric substances with 85 to $95 \%$ of water and thus can cause binding of various pathogens (especially bacteria) to live tissues and surfaces of medical equipment(7). This property enhances the bacterial resistance to a variety of antibiotics and host defense mechanisms, as well as facilitates metabolism gene transfer and resistance to antibiotics and disinfectants(7). Promoting the bacterial survival in harsh environmental conditions, playing a role in pathogenesis and causing chronic diseases, and influencing the development and enhancement of drug resistance through impermeability to antibiotics in the polymer matrix, are the most important features of 
biofilm(8). S. aureus adhesion genes involved in the cellular accumulation of bacteria in biofilms include fib, fnbA, fnbB, eno, icaADBC, sasG,sasC and p/s(9). However, fibronectin-binding proteins A and B (FnBPA and FnBPB) are encoded by the $f n b A$ and $f n b B$ genes, respectively(10). These proteins can be covalently attached to the bacterial cell and play an important role in initiating the biofilm production process by binding to fibronectin receptors(9). On the other hand, the production of fibronectin-binding proteins (FnBP) is essential for the invasion of this organism to eukaryotic cells(11). The ability to form biofilms is mediated by intercellular adhesin polysaccharides (PIAs) encoded by IcaA, IcaB, IcaC, and IcaD genes, which thicken the biofilm layers $(2,9)$.In contrast, fibronectin-binding proteins (FnBPA and FnBPB) play important roles in the accumulation, binding and invasion of $S$. aureus to surfaces(12).So, the current study aims to evaluate the biofilm formation by $S$. aureus and to determine the prevalence of fibronectinbinding protein genes, also its correlation with drug resistance.

\section{Materials And Methods}

\section{Sample collection}

In this study, 100 non-duplicate $S$. aureus isolates were collected during 10 months (March to December 2019) from different clinical specimens (blood, urine, ulcer, pus, body fluids, trachea, sputum, etc.) of patients admitted to Zare hospital of Sari city (a burn center) and Imam Khomeini hospital of Behshahr city (a general center).The isolates were transferred to the Microbiology Laboratory and cultured in Blood Agar (Merck, Germany) and incubated at $37^{\circ} \mathrm{C}$ for 24 hours. Then, all isolates were identified by standard microscopic and biochemical methods such as gram staining, catalase and coagulase assays, mannitol fermentation and DNase assay(13), and were confirmed by PCR using nuc gene-specific primers. $S$. aureus ATCC 25923 was used as a control strain for diagnostic tests.

\section{Antimicrobial susceptibility testing (AST)}

The antibiotic susceptibility pattern of the isolates against 6 antibiotics including penicillin $(10 \mu \mathrm{g})$, vancomycin $(30 \mu \mathrm{g})$, erythromycin $(15 \mu \mathrm{g})$, tetracycline $(30 \mu \mathrm{g})$, ciprofloxacin $(5 \mu \mathrm{g})$, and clindamycin (2 $\mu \mathrm{g}$ ) (Roscoe, Denmark) was determined by Kirby-Bauer method according to the guidelines of the Clinical and Laboratory Standards Institute (CLSI)(15). We chose the S. aureus ATCC 25923 as a control strain in AST. Also, micro broth dilution method based on the CLSI guidelines was used to evaluate the minimum inhibitory concentration (MIC) of vancomycin, and S. aureus ATCC 29213 was used as a standard strain in this study(15).

\section{Phenotypic assessment of biofilm production}

The capability of biofilm formation in the isolates was investigated by microtiter plate method(16). Briefly, $180 \mu \mathrm{l}$ of TSB (trypticase soy broth) containing 1\% glucose was poured into 96 well microplate wells. Then, $20 \mu$ of $0.5 \mathrm{McF}$ arland's equivalent bacterial suspension was added to TSB medium in each well. Next, the microplates were incubated at $37^{\circ} \mathrm{C}$ for $20 \mathrm{~h}$. After the contents were thoroughly discharged from the wells and washed three times with $0.15 \mathrm{M}$ PBS (phosphate-buffered saline), the microplates were 
completely air-dried. Then, the wells were stained with $0.1 \%$ crystal violet.After dye evacuation, we washed the wells three times with distilled water and added $200 \mu \mathrm{l}$ alcohol-acetone (1:4 ethanol to acetone) to the wells in order to release the dye on the wall of bacteria producing biofilm and attached to the well. The amount of dye released at each well was evaluated using the ELISA reader (Biotech, USA) at $590 \mathrm{~nm}$. The OD of the samples were then compared with the OD of the control (ODC) and the results were analyzed using the cut-off method. The isolates which showed $O D \leq O D C$, were considered as no biofilm producers, while the results as ODC $\angle O D \leq 2 \times O D C, 2 \times O D C<O D \leq 4 \times O D C$, and $4 \times O D C<O D$ were reflected as weak, moderate, and strong biofilm producer isolates, respectively. The TSB medium containing $1 \%$ glucose was used as the negative control, while $S$. aureus ATCC 35556 was used as a positive control (biofilm-producing strain) in this test(16).

\section{Molecular analysis of $n u c, f n b A$ and $f n b B$ genes}

Genomic DNAs were extracted from clinical isolates of $S$. aureus using a DNA extraction kit (SinaClon, Iran) according to manufacturer's instructions. To confirm the purity of the extracted DNAs, a Nanodrop machine (Thermo Scientific, USA) at $260 \mathrm{~nm}$ was used, and the DNAs were electrophoresed on $1.5 \%$ agarose gel (Wizbiosolutions, South Korea). PCR was used to identify the nuc gene (for the final confirmation of $S$. aureus isolates) and to detect the presence of $f n b A$ and $f n b B g e n e s$ in clinical isolates. Primers sequences for the identification of target genes have been described previously $(8,14)$. The PCR reaction was performed in a final volume of $25 \mu \mathrm{l}$, consisting of $12.5 \mu \mathrm{l}$ of premix (Denmark, Ampliqon), 10 picomoles of each primer, $1 \mu \mathrm{l}$ of Taq DNA polymerase, $5 \mu \mathrm{l}$ of distilled water, and $300 \mathrm{ng}$ of template DNA. A thermal cycler (SensoQuest $\mathrm{GmbH}$, Germany) was used to amplify the mentioned genes. The PCR reaction consisted of an initial denaturation step at $95^{\circ} \mathrm{C}$ for 2 minutes and 30 cycles of denaturation at $95^{\circ} \mathrm{C}$ for 25 seconds, followed by $30 \mathrm{~s}$ of the annealing stage at $53^{\circ} \mathrm{C}$ for the nuc gene, $52^{\circ} \mathrm{C}$ for the fnbA gene, and $55^{\circ} \mathrm{C}$ for the $f n b B$ gene, and extension at $72^{\circ} \mathrm{C}$ for $30 \mathrm{~s}$, along with a final amplification step at $72^{\circ} \mathrm{C}$ for $5 \mathrm{~min}$. PCR products were electrophoresed on a $1.5 \%$ agarose gel (Wizbio, Korea) along with a DNA fragment length marker (GeneDireX, Taiwan) to investigate the presence of the target genes.

\section{Statistical Analysis}

Data were analyzed by SPSS software (version 22) and mean of quantitative data was analyzed using Descriptive software and were presented as Mean \pm SD. Also, the significance level was evaluated by twotailed and chi-square tests and P-value< 0.05 was considered statistically significant.

\section{Results}

Out of 100 clinical isolates of $S$. aureus in this study according to the presence of nuc gene, 50 isolates were obtained from Zare Hospital and 50 others were collected from Imam Khomeini Hospital. The mean age of the patients was $42.59 \pm 24.94$ years. The mean age for men and women was $47.04 \pm 24.05$ and $38.15 \pm 25.25$, respectively. There was no significant difference between the two groups in terms of mean age $(P=0.07)$.The distribution of the isolates, in terms of hospital wards, was as follows: ICU $(29 \%)$, burn 
$(23 \%)$, reconstructive surgery $(13 \%)$, pediatric $(12 \%)$, internal $(11 \%)$, gynecological surgery $(5 \%)$, male surgery $(3 \%)$, emergency $(2 \%)$ and CCU $(2 \%)$.

Also, there was a significant difference $(P=0.000)$ in the distribution of clinical specimens from different wards between two hospitals, however, the highest frequency of clinical specimens in Imam Hospital included ICU (16 samples, 32\%), and internal and Pediatrics (11 samples, 22\%), while the most frequent isolates in the Zare Hospital belonged to burn ward (23 samples, 46\%) and ICU ( 13 samples, $26 \%$ ).In general, the frequency of clinical specimens in the present study was as follows: wounds (36\%), urine (29\%), blood (21\%), trachea (9\%), surgical samples (2\%), ascites, pulmonary secretions and sputum each (1\%).According to the evaluation of antibiotic resistance pattern of the isolates in this study, the highest antibiotic resistance rate was observed against penicillin (94\%), tetracycline $(50 \%)$ and erythromycin $(42 \%)$, while vancomycin, with $6 \%$ resistance rate, was the most effective antibiotic in this research (Table 1). The MIC range of vancomycin against the isolates was $0.25-32 \mu \mathrm{g} / \mathrm{ml}$, which was consistent with the results of the disk agar diffusion method. In this study, $4 \%, 9 \%, 42 \%, 32 \%, 7 \%$, and $6 \%$ of the isolates showed a MIC range of $0.25,0.5,1,2,4$, and $32 \mu \mathrm{g} / \mathrm{ml}$, while any of the isolates exhibited a MIC range of $8-16$ and $\geq 64 \mu \mathrm{g} / \mathrm{ml}$. Statistical analysis of antibiotic resistance results by the chi-square test showed no significant difference between antibiotic resistance pattern of $S$. aureus isolates in two sex groups, different parts of hospitals and different clinical samples ( $P>0.05)$.Moreover, $32 \%$ of our clinical isolates showed multidrug resistance (MDR) phenotype. The antibiotic resistance pattern of the MDR and nonMDR clinical isolates of $S$. aureus is compared in Table 2. The results indicate higher antibiotic resistance of MDR strains than non-MDR strains. In this study, $f n b A$ and $f n b B g e n e s$ were identified in $91 \%$ and $17 \%$ clinical isolates of $S$. aureus, respectively. Of the isolates studied, 89 were able to produce biofilms (Table $3)$. Biofilm production ability was strong in 54 isolates $(60.67 \%)$, moderate in 28 isolates $(31.46 \%)$ and weak in 7 isolates $(7.86 \%$ ) (Table 4 ). The frequencies of $f n b A$ and $f n b B$ genes in biofilm-producing strains and non-biofilm producer ones are shown in Table 4. Significant differences were observed in the frequency of $f n b A$ and $f n b B$ genes between biofilm producer and non-biofilm producing isolates in this study $(p<0.05)$.Also, there was a significant difference in the frequency of $f n b A$ gene between MDR and non-MDR isolates, while there was no significant difference in $f n b B$ gene frequency in these isolates (Table 5). The frequency of biofilm production in MDR and non-MDR strains was $100 \%$ and $83.82 \%$, respectively.

\section{Discussion}

S. aureus is one of the most important bacteria causing nosocomial infections (17). The high ability of this bacterium in biofilm production has led to the occurrence of chronic infections and the emergence of multi-drug resistant $S$. aureus strains (17). The ability to produce biofilms is one of the most important virulence factors in $S$. aureus that allows the organism to bind to different levels and increase the antibiotic resistance level, which ultimately leads to increased mortality in hospitals. In the present study, the highest and lowest antibiotic resistance were reported for penicillin and vancomycin, respectively, which was almost similar to the results of another Iranian study conducted in 2016(1). In their study, 100 and $2 \%$ of the isolates were resistant to penicillin and vancomycin, respectively. Similar results were also 
reported by Rahimi and his colleagues in 2013 from Iran, while their isolates were collected from the poultry sources, and all of the isolates were methicillin-resistant (18). The high resistance of the isolates to penicillin in Iran was expected to be similar to the results obtained by other Iranian researchers. This may be due to lack of attention to drug dosage, empirical treatment regardless to antibiogram results, incomplete treatment, overdose and over-the-counter use of penicillin family antibiotics, use of penicillins in aviculture, and high levels of beta-lactamase production by $S$. aureus(19). The evaluation of biofilm production ability in the present study showed that $89 \%$ of the isolates studied were capable to produce biofilms, while in other study conducted in Iran (1), all of their clinical isolates were biofilm producers. However, the clinical samples of the mentioned study were similar to our research. In a study conducted by Vuong et al. in Germany, $78 \%$ of $S$. aureus clinical isolates were biofilm producer (20). The percentage of biofilm production power varies in different studies but in most studies is high level indicating the important role of biofilm production ability in the pathogenicity of $S$. aureus in clinical practice. While in the present study a total of $91 \%$ of $S$. aureus isolates were positive for the presence of $f n b A$ gene, in a study carried out by Nashev et al. on clinical isolates obtained from skin and nose in hospitals of Germany, $36.7 \%$ of the isolates carried the $f n b A$ gene(21). Also, in a study conducted by Soltani and colleagues in Iran in 2019 on strains isolated from nasal swabs, 7.2\% of the isolates contained $f n b A$ gene (22). The reason for these differences may be related to the type of clinical samples, whereas the skin and nose isolates are normal flora and the virulence factors associated with the pathogenicity are less common in these bacteria.A study performed in the USA on clinical isolates reported the prevalence of $98.7 \%$ and $20.1 \%$ for $f n b A$ and $f n b B$ genes, respectively (23), which was much closed to the results of the present study. On the other hand, a study conducted in India also showed a high prevalence of both fnbA and $f n b B$ genes ( $77.8 \%$ and $81 \%$, respectively), which is consistent with the results of our study regarding fnbA gene (24). Interestingly, Arciola et al. exhibited that $98 \%$ of Staphylococcus aureus isolates associated with orthopedic infections contained fnbA\&B genes, indicating the important role of these virulence factors in biofilm production in various infections, especially orthopedic ones(25).Abbas and his colleagues in Iraq, the border with Iran, reported 59\% $n n b A$ gene frequency(26), while in 2019, Azmi et al. reported the frequency of $f n b A a n d f n b B$ genes in Palestine as $78.2 \%$ and $29 \%$, respectively (27). These differences in the prevalence of $f n b$ genes indicate the genetic diversity of clinical isolates of $S$. aureus in different regions of the world and the necessity to study this diversity in each region.Also, $32 \%$ of Staphylococcus aureus clinical isolates were MDR in the present study, which showed significantly higher resistance to ciprofloxacin, tetracycline, clindamycin and erythromycin than non-MDR strains.Two other studies conducted in Iran and Palestine also reported $46 \%$ and $26.6 \%$ prevalence of MDR clinical isolates of $S$. aureus, respectively $(27,28)$. However, the MDR rate between strongly positive biofilm-producing isolates in the Palestinian research was reported as $38.5 \%$, while this rate in our study was $66.6 \%$. It seems that strongly biofilm-production had a great impact on the development of antibiotic resistance in our research. On the other hand, we found that the frequency of $f n b A$ and $f n b B$ genes in MDR strains were $100 \%$ and $21.9 \%$, respectively, and all of these isolates were capable of biofilm formation. However, in the study by Azmi et al., $26.6 \%$ of the isolates were MDR, while $50.7 \%$ and $20 \%$ of MDR isolates carried $f n b A$ and $f n b B$ genes, respectively, and all of which were detected as biofilm producer isolates (27).Today, with increasing use of antibiotics and increasing prevalence of methicillin and vancomycin resistant 
Staphylococcus aureus strains and the high ability of this organism in biofilm production, the treatment of infections caused by it has become a major challenge in the world $(3,29)$.

\section{Conclusions}

In conclusion, based on our results, it can be argued that clinical isolates of $S$. aureus have a high ability to form biofilms and fnb genes with high diversity and high prevalence play an important role in biofilm construction. Also, given the high prevalence of the $f n b A$ gene, it can be expected that the isolates containing this gene play a more effective role in pathogenesis. Although one of the major causes of infection emergence and drug resistance is attributed to biofilm production, and the presence of related genes, but by identifying and inhibiting the genes, sources, and pathways of infection transmission, we can prevent the biofilm formation and reduce the antibiotic pressure, and the selection of the most effective antibiotics for the treatment of the infections, and on the other hand, it can prevent the spread of resistance genes and the emergence of strains with multidrug resistance phenotype.

\section{Declarations}

\section{Acknowledgements}

This study was supported by the Mazandaran University of Medical Sciences, Sari, Iran with the Grant number: 1466. Also, we thank the laboratory staffs of Imam Khomeini and Zare hospitals for assist in the collection of the clinical isolates.

\section{Conflict of interest}

The authors declare that they have no conflict of interest.

\section{Availability of data and materials}

Data generated and/or analyzed during this study are included in this article.

\section{Authors'Contributions}

Conceptualization: [Hamid Reza Goli], Methodology: [Mohammad Ahanjan and Mehrdad Gholmi], Formal analysis and investigation: [Hossein Jafari Soghondicolaei and Bahman Mirzaei], Writing - original draft preparation: [Hossein Jafari Soghondicolaei andHamid Reza Goli]; Writing - review and editing: [Mehrdad Gholami and Hamid Reza Goli].All authors read and approved the final manuscript.

\section{Ethics approval}

This study was approved by the Ethics Committee of the Mazandaran University of Medical Sciences, Sari, Iran (Approved Number: IR.MAZUMS.REC.1397.1466) and Iran National Committee for Ethics in Biomedical Research (Approved Number: IR.MAZUMS.REC.1397.312). Although, we did not have a direct 
connection with the patients, the informed written consent was obtained from patients. We only obtained the clinical samples of the patients without their names from the hospital laboratories and the data was kept secret by the authors.

\section{Consent to Participate}

All individual participantssigned an informed consent to participation in the work.

\section{Consent for publication}

Patients signed informed consent regarding publishing their data.

\section{References}

1. Shahmoradi M, Faridifar P, Shapouri R, Mousavi SF, Ezzedin M, Mirzaei B (2019) Determining the Biofilm Forming Gene Profile of Staphylococcus aureus Clinical Isolates via Multiplex Colony PCR Method. Rep Biochem Mol Biol no. 7:181-188

2. Archer NK, Mazaitis MJ, Costerton JW, Leid JG, Powers ME, Shirtliff ME. Staphylococcus aureus biofilms: properties, regulation, and roles in human disease. Virulence. 2011, no. 2, pp. 445-59

3. Kong C, Neoh HM, Nathan S (2016) Targeting Staphylococcus aureus toxins: a potential form of antivirulence therapy. Toxins no. 8:72-93

4. Kim MK, Drescher K, Pak OS, Bassler BL, Stone HA (2014) Filaments in curved streamlines: rapid formation of Staphylococcus aureus biofilm streamers. New J Phys no. 16:065024-065046

5. Bridier A, Sanchez-Vizuete Mdel P, Le Coq D, Aymerich S, Meylheuc T, Maillard JY, Thomas V, DuboisBrissonnet F, Briandet R (2012) Biofilms of a Bacillus subtilis hospital isolate protect Staphylococcus aureus from biocide action. PLoS One no. 7:e44506

6. Kim SJ, Chang J, Rimal B, Yang H, Schaefer J (2018) Surface proteins and the formation of biofilms by Staphylococcus aureus. BBA Biomembranes no. 1860:749-756

7. Moormeier DE, Bayles KW (2017) Staphylococcus aureus biofilm: a complex developmental organism. Mol Microbiol no. 104:365-376

8. Atshan SS, Nor Shamsudin M, Sekawi Z, Lung LTT, Hamat RA, Karunanidhi A, Ali AM, Ghaznavi-Rad E, Ghasemzadeh-Moghaddam H, Chong Seng JS, Nathan J, J., and Pei P, C. Prevalence of adhesion and regulation of biofilm-related genes in different clones of Staphylococcus aureus. BioMed. Res. Int. 2012, no. 2012, pp. 1-10

9. Avila-Novoa MG, Iñíguez-Moreno M, Solís-Velázquez O-A, González-Gómez J-P, Guerrero-Medina P-J, Gutiérrez-Lomelí M Biofilm Formation by Staphylococcus aureus Isolated from Food Contact Surfaces in the Dairy Industry of Jalisco, Mexico. J. Food. Quality. 2018, no. 2018, pp. 1-8

10. O'Neill E, Pozzi C, Houston P, Humphreysm H, Robinson DA, Loughman A, Foster TJ, O'Gara JP A novel Staphylococcus aureus biofilm phenotype mediated by the fibronectin-binding proteins, FnBPA and FnBPB. J. Bacteriol. 2008, no. 190, pp. 3835-50 
11. Mahdavi S Frequency of Adherence Genes cna, fnbA and fnbB in Staphylococcus aureus Isolates from Traditional Cheese. Med. Lab. J. 2017, no. 11, pp. 11-15

12. Speziale P, Pietrocola G, Foster TJ, Geoghegan JA Protein-based biofilm matrices in Staphylococci. Front. Cell. Infect. Microbiol. 2014, no. 10, pp. 171

13. Tille $P$ (2015) Bailey \& Scott's diagnostic microbiology-E-Book. Elsevier Health Sciences

14. Cremonesi P, Luzzana M, Brasca M, Morandi S, Lodi R, Vimercati C, Agnellini D, Caramenti G, Moroni P, Castiglioni B (2005) Development of a multiplex PCR assay for the identification of Staphylococcus aureus enterotoxigenic strains isolated from milk and dairy products. Mol Cell Probes no. 19:299-305

15. In C (2018) Performance standards for antimicrobial susceptibility testing. Clinical and Laboratory Standards Institute (CLSI), Wayne

16. Halebeedu PP, Rajan V, Gopal S (2017) Predominance of SCCmec types IV and V among biofilm producing device-associated Staphylococcus aureus strains isolated from tertiary care hospitals in Mysuru, India. Enferm Infect Microbiol Clin no. 35:229-235

17. Jenkins DR (2017) Nosocomial infections and infection control. Medicine no. 45:629-633

18. Rahimi F, Karimi S Characteristics of methicillin resistant staphylococcus aureus strains isolated from poultry in iran. Arch. Clin. Infect. Dis. 2015, no. 10, pp. e30885

19. Hao H, Dai M, Wang Y, Huang L, Yuan Z (2012) Key genetic elements and regulation systems in methicillin-resistant Staphylococcus aureus. Future Microbiol no. 7:1315-1329

20. Vuong C, Saenz HL, Gotz F, Otto M (2000) Impact of the agr quorum-sensing system on adherence to polystyrene in Staphylococcus aureus. J Infect Dis no. 182:1688-1693

21. Nashev D, Toshkova K, Salasia SIO, Hassan AA, Lämmler C, Zschöck M (2004) Distribution of virulence genes of Staphylococcus aureus isolated from stable nasal carriers. FEMS Microbiol Lett no. $233: 45-52$

22. Soltani E, Farrokhi E, Zamanzad B, Abadi MSS, Deris F, Soltani A, Gholipour A Prevalence and distribution of adhesins and the expression of fibronectin-binding protein (FnbA and FnbB) among Staphylococcus aureus isolates from Shahrekord Hospitals. BMC. Res. Notes. 2019, no. 12, pp. 49

23. Booth MC, Pence LM, Mahasreshti P, Callegan MC, Gilmore MS Clonal associations among Staphylococcus aureus isolates from various sites of infection. Infect. Immun. 2001, no. 69, pp. 345-52

24. Gowrishankar S, Kamaladevi A, Balamurugan K, Pandian SK In vitro and in vivo biofilm characterization of methicillin-resistant Staphylococcus aureus from patients associated with pharyngitis infection. BioMed. Res. Int. 2016, no. 2016

25. Arciola CR, Campoccia D, Gamberini S, Baldassarri L, Montanaro L Prevalence of cna fnbA and fnbB adhesin genes among Staphylococcus aureus isolates from orthopedic infections associated to different types of implant. FEMS. Microbiol. Lett. 2005, no. 246, pp. 81-6 


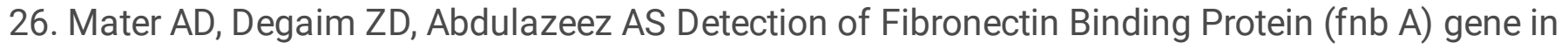
Staphylococcus aureus isolates. J. Univesity. Thi-Qar. 2019, no. 14, pp. 10-6

27. Azmi K, Qrei W, Abdeen Z (2019) Screening of genes encoding adhesion factors and biofilm production in methicillin resistant strains of Staphylococcus aureus isolated from Palestinian patients. BMC Genomics no. 20:578

28. Rahimi F, Bouzari M, Katouli M, Pourshafie MR Antibiotic resistance pattern of methicillin resistant and methicillin sensitive Staphylococcus aureus isolates in Tehran, Iran. Jundishapur. J. Microbiol. 2013 , no. 6 , pp. $144-9$

29. Eshaghi M, Bibalan MH, Pournajaf A, Gholami M, Talebi M (2017) Detection of new virulence genes in mecA-positive Staphylococcus aureus isolated from clinical samples: the first report from Iran. Infectious Diseases in Clinical Practice 25(6):310-313

\section{Tables}

Table 1

Antibiotic resistance pattern of $100 \mathrm{~S}$. aureus clinical isolates

\begin{tabular}{|llll|}
\hline \multirow{2}{*}{ Antibiotics } & \multicolumn{3}{l|}{ Percentage of the isolates which were } \\
\cline { 2 - 4 } & Resistant & Intermediate & Susceptible \\
\hline Ciprofloxacin & 37 & 16 & 47 \\
\hline Penicillin & 94 & - & 6 \\
\hline Tetracycline & 50 & 40 & 10 \\
\hline Vancomycin & 6 & - & 94 \\
\hline Clindamycin & 35 & 16 & 49 \\
\hline Erythromycin & 42 & 24 & 34 \\
\hline
\end{tabular}


Table 2

Comparison of antibiotic resistance pattern of MDR and non-MDR S. aureus

\begin{tabular}{|c|c|c|c|c|}
\hline \multirow[t]{2}{*}{ Antibiotics } & \multirow[t]{2}{*}{ Resistance pattern } & & & \multirow[t]{2}{*}{ P-Value } \\
\hline & & $\begin{array}{l}\text { MDR isolates }(n= \\
32)\end{array}$ & $\begin{array}{l}\text { Non-MDR isolates }(n= \\
68)\end{array}$ & \\
\hline \multirow[t]{3}{*}{ Ciprofloxacin } & Resistant & $32(100)$ & $5(7.35)$ & \multirow[t]{3}{*}{0.01} \\
\hline & $\begin{array}{l}\text { Intermediate } \\
\text { Resistant }\end{array}$ & - & $16(23.52)$ & \\
\hline & Susceptible & - & $47(69.11)$ & \\
\hline \multirow[t]{3}{*}{ Penicillin } & Resistant & $32(100)$ & $62(91.17)$ & \multirow[t]{3}{*}{0.1} \\
\hline & $\begin{array}{l}\text { Intermediate } \\
\text { Resistant }\end{array}$ & - & - & \\
\hline & Susceptible & - & $6(8.82)$ & \\
\hline \multirow[t]{3}{*}{ Tetracycline } & Resistant & $32(100)$ & $18(26.47)$ & \multirow[t]{3}{*}{0.04} \\
\hline & $\begin{array}{l}\text { Intermediate } \\
\text { Resistant }\end{array}$ & - & $40(58.82)$ & \\
\hline & Susceptible & - & $10(14.7)$ & \\
\hline \multirow[t]{3}{*}{ Vancomycin } & Resistant & - & $6(8.82)$ & \multirow[t]{3}{*}{0.02} \\
\hline & $\begin{array}{l}\text { Intermediate } \\
\text { Resistant }\end{array}$ & - & - & \\
\hline & Susceptible & $32(100)$ & $62(91.17)$ & \\
\hline \multirow[t]{3}{*}{ Clindamycin } & Resistant & $28(87.5)$ & $7(10.29)$ & \multirow[t]{3}{*}{0.02} \\
\hline & $\begin{array}{l}\text { Intermediate } \\
\text { Resistant }\end{array}$ & $3(9.37)$ & $13(19.11)$ & \\
\hline & Susceptible & $1(3.12)$ & $48(70.58)$ & \\
\hline \multirow[t]{3}{*}{ Erythromycin } & Resistant & $32(100)$ & $10(14.7)$ & \multirow[t]{3}{*}{0.03} \\
\hline & $\begin{array}{l}\text { Intermediate } \\
\text { Resistant }\end{array}$ & - & $24(35.29)$ & \\
\hline & Susceptible & - & $34(50)$ & \\
\hline
\end{tabular}


Table 3

Frequency of fnbA and fnbB genes in biofilm producer and non-biofilm producer

S. aureus

\begin{tabular}{|llll|}
\hline Genes & Biofilm producer & Non-biofilm producer & P-value \\
\hline fnbA Positive $(n=91)$ & $83(91.2 \%)$ & $8(8.79 \%)$ & 0.025 \\
\hline fnbA Negative $(n=9)$ & $6(66.66 \%)$ & $3(33.33 \%)$ & NS \\
\hline fnbB Positive $(n=17)$ & $16(94.11 \%)$ & $1(5.88 \%)$ & 0.01 \\
\hline fnbB Negative $(n=83)$ & $73(87.95 \%)$ & $10(12.04 \%)$ & NS \\
\hline
\end{tabular}

NS, Not Statistically significant

Table 4

Distribution of biofilm production ability and its relation to the presence of fnbA and fnbB genes in $S$. aureus isolates

\begin{tabular}{|c|c|c|c|c|}
\hline \multirow{2}{*}{$\begin{array}{l}\text { Strains with or without } \\
\text { genes }\end{array}$} & \multicolumn{4}{|c|}{ The ability of biofilm production } \\
\hline & $\begin{array}{l}\text { Strong No. } \\
(\%)\end{array}$ & $\begin{array}{l}\text { Moderate No. } \\
(\%)\end{array}$ & $\begin{array}{l}\text { Weak No. } \\
(\%)\end{array}$ & $\begin{array}{l}\text { No biofilm No. } \\
(\%)\end{array}$ \\
\hline $\begin{array}{l}\mathrm{fnbA}^{+} \\
(\mathrm{n}=91)\end{array}$ & $48(52.74)$ & $28(30.76)$ & 7 (7.69) & 8 (8.79) \\
\hline $\begin{array}{l}\mathrm{fnbA}^{-} \\
(\mathrm{n}=9)\end{array}$ & $6(66.66)$ & - & - & 3 (33.33) \\
\hline $\begin{array}{l}\mathrm{fnbB}^{+} \\
(\mathrm{n}=17)\end{array}$ & $13(76.47)$ & $3(17.64)$ & - & $1(5.88)$ \\
\hline $\begin{array}{l}\mathrm{fnbB}^{-} \\
(\mathrm{n}=83)\end{array}$ & 41 (49.39) & $25(30.12)$ & $7(8.43)$ & $10(12.04)$ \\
\hline $\begin{array}{l}f_{n b A^{+} \& B^{+}} \\
(n=15)\end{array}$ & 13 (86.66) & 2 (13.33) & - & - \\
\hline $\begin{array}{l}\mathrm{FnbA}^{-} \& \mathrm{~B}^{-} \\
(\mathrm{n}=6)\end{array}$ & $5(83.33)$ & - & - & $1(16.66)$ \\
\hline
\end{tabular}


Table 5

Frequency of fnbA and fnbB genes in MDR and nonMDR S. aureus isolates

\begin{tabular}{|lll|}
\hline Genes & MDR $(\mathbf{n = 3 2})$ & Non-MDR $(\mathbf{n}=\mathbf{6 8})$ \\
\hline fnbA Positive & $32(100 \%)$ & $59(86.76 \%)$ \\
\hline fnbA Negative & - & $9(13.23 \%)$ \\
\hline P-value & 0.000 & NS \\
\hline fnbB Positive & $7(21.87 \%)$ & $10(14.7 \%)$ \\
\hline fnbB Negative & $25(78.12 \%)$ & $58(85.29 \%)$ \\
\hline P-value & NS & NS \\
\hline
\end{tabular}

NS, Not Statistically significant 